\title{
Enhancing intra-regional grain trade in Eastern Africa through market information systems: The case of the Regional Agricultural Trade Intelligence Network (RATIN)
}

\section{Janet Ngombalu \\ Gerald Masila}

Eastern African Grain Council Maple Court

Westlands Close

Off Westlands Rd

P.O. Box 218

00606 Sari Centre

Nairobi

Kenya

$<$ jngombalu@eagc.org $>$

$<$ gmasila@eagc.org >
Reprints: J. Ngombalu doi: 10.1684/agr.2014.0711

\begin{abstract}
The Eastern Africa Grain Council (EAGC) focuses on promoting intra-regional trade in Africa in order to expand access to markets by the small holder farmers and traders. However, the lack of market information still remains a challenge, not only to farmers, but to all stakeholders in the value chain, as well as governments. Therefore, market information is largely considered a public good and its impact in facilitating and promoting regional trade can lead to increased earning for farmers, reduced transaction costs, increased regional trade, price stabilization, and improved food security. The provision of the market information system by the EAGC, the Regional Agricultural Trade Intelligence Network (RATIN), is discussed in this paper. A description of RATIN is provided with a discussion of the structure, conduct, and performance, as well as an examination of how RATIN has contributed to increased regional trade for grain in the Eastern Africa region, including a discussion regarding the challenges, lessons learned, and some conclusions.
\end{abstract}

Key words: food policies; food security; information and communication technologies (ICTs); market information services (MIS).

Subjects: economy and rural development; food processing, marketing; tools and methods.

\section{Résumé}

Améliorer le commerce intrarégional des céréales en Afrique de l'Est par les systèmes d'information de marché : le cas du réseau RATIN (Regional Agricultural Trade Intelligence Network)

Le Conseil céréalier est-africain (EAGC) s'emploie à promouvoir le commerce intrarégional en Afrique, en vue d'élargir l'accès aux marchés pour les petits exploitants agricoles et les commerçants. Cependant, le manque d'informations de marché reste un défi non seulement pour les agriculteurs, mais pour tous les intervenants dans la chaîne de valeur et pour les gouvernements. Aussi les informations de marché sont-elles considérées comme un bien public, dont l'impact sur le développement et la promotion du commerce régional peut augmenter les revenus des agriculteurs, réduire les coûts de transaction, accrôtre le commerce régional, stabiliser les prix et améliorer la sécurité alimentaire. Cet article présente le système d'information de marché RATIN (Regional Agricultural Trade Intelligence Network) fourni par EAGC. Il donne une description de RATIN, présente sa structure, son comportement et ses performances. Il examine également comment RATIN a contribué à accroître le commerce régional de céréales en Afrique de l'Est et aborde les défis, les leçons apprises et les conclusions tirées.

Mots clés : politiques alimentaires ; sécurité alimentaire ; service d'information marchés (SIM) ; technologies de l'information et de la communication (TIC).

Thèmes : économie et développement rural ; méthodes et outils ; transformation, commercialisation.
To cite this article: Ngombalu J, Massila G, 2014. Enhancing intra-regional grain trade in Eastern Africa through market information systems: The case of the Regional Agricultural Trade Intelligence Network (RATIN). Cah Agric 23: 270-81. doi : 10.1684/agr.2014.0711 


\section{Introduction}

Agriculture in Africa is the main source of livelihood for the rural economy and has a powerful though indirect influence on traditions, structural orientation, lifestyles, and rural land use. In general, about two thirds of Africa's poor people live in rural areas and depend on agriculture for their survival, with low and often declining farm level productivity being major causes of persistent low incomes and hunger (AATF, 2004). The same pattern is reflected in the East Africa Community (EAC) where about 80\% population live in the rural areas and derive their livelihood largely from agriculture.

Therefore, since the majority of the population in Africa is dependent on agriculture, selling their agricultural produce is their primary source of income, which is used to meet various household needs including education, health, and complementing their nutritional needs by buying foods that they do not produce. However, agriculture in Africa is predominantly small holder-based and is characterized by many challenges which include small and uneconomical parcels of land, low mechanization, and usage of farm inputs including use of certified seeds. As a result, agricultural productivity in Africa still lags behind the other regions of the world and has continued to decline over the years. In addition, access to market by the rural small holder farmers also remains a challenge as they often have to part with their produce at the farm gate, soon after harvest. Lack of market information, such as the prevailing market prices, trends, and the market demand and supply, means that the small holder farmer cannot effectively negotiate a price for his/her produce. Consequently, the farmers end up with low returns for their produce and this perpetuates the vicious circle of poverty.

The marketing and trade of agricultural products plays a critical role in the spatial distribution of produce from production areas to markets. However, trade of most agricultural products, more so staple foods, is generally not well organized and is often subjected to many state regulations when it comes to intra-regional cross-border trade. Policy responses include: import tariffs for the objective of protecting local producers and export tariffs or even bans for the objective of ensuring food security for the local population. These policy instruments are generally not predictable and sometimes are applied without any notice to the stakeholders. As a result, most stakeholders employ a "wait and see" strategy and decisions taken both on the supply and demand side of the equation are short-term. The short-term approach further exacerbates the price volatility phenomenon with the overall trend being a general increase in food prices owing to the low levels of investments in the sector as a result of the high risks associated with the sector.

\section{Intra-regional trade in agricultural products}

The need to promote and facilitate intra-regional trade has been cited by many stakeholders, including governments. One of the driving forces and objectives of the various regional economic blocs is to promote intraregional trade by opening up the borders and availing larger markets for producers for economies of scale which benefits both producers and consumers.

Africa is on the right path of intraregional trade, but lags behind other global regions. Exports from Africa have continuously increased significantly, especially in the last eight years. However, Africa has not kept pace with trade flows in the rest of the world which roughly tripled between 1990 and 2006. During this same period, intra-regional trade within emerging Asia increased eight fold. By 2007, intra-regional trade accounted for more than 50\% of total trade in East Asia. However, intraregional trade in Africa remains low and accounts for less than 10\% of total trade. Between 1999 and 2006, for example, intra-African trade increased by an average of just 14\% per year, while trade with the United States and China expanded by 26 and 61\%; respectively (EAC, 2011). Despite the low level of intra-African trade at the regional level, in some African countries intra-regional trade is significant.
Intra-regional trade in Africa has remained low over the years as cross-border barriers to trade are the order of the day in a continent that has the highest number of borders in the world. However, the EAC recently reported that the intra-regional trade in EAC had grown by $49 \%$ in the last five years with an increased interest to liberalize and promote cross-border trade among member states of the regional bloc; Tanzania, Uganda, Kenya, Burundi, and Rwanda.

The lack of market information is a challenge, not only to farmers, but to all stakeholders in the value chain, as well as governments. Often, governments institute policy responses without sufficient information to back up their decisions. Therefore, the need and demand for market information is largely a public good and its impact in facilitating and promoting regional trade can lead to increased earning by farmers, reduced transaction costs, increased regional trade, price stabilization, and improved food security. Many organisations have attempted to establish and operate market information services. Government ministries also expend considerable efforts to collect and disseminate market information with varying degree of success. However, stakeholder confidence in the market information provided by governments has generally been low and they ultimately do not rely much on this information.

\section{The market information system by the Eastern Africa Grain Council}

The Eastern Africa Grain Council (EAGC) is a regional, non-profit, membership council of firms and organizations in the grain value chain established in 2006, with a mandate covering 10 countries in the Eastern Africa region. The membership of the EAGC is comprised of key stakeholders in the grain value chain, including grain producers/farmers, traders, processors, and other interested organizations and service 
providers, such as input suppliers, financial institutions, among others. The vision is "to be a leading voice of the private sector in the grain industry in Africa" so as to positively influence policy and practice in market development and trade facilitation in the Eastern Africa region. The key objective of the EAGC is to develop, influence, and promote frameworks for structured grain trading as a means to better integrated national and regional grain markets, resulting in increased intra- and inter-regional grain trade governed by defined and harmonized predictable policies, rules of trade, regulations, standards, and a transparent price discovery mechanism.

The EAGC business model focuses on provision of services to facilitate: investment in development of market infrastructure and institutions at national and regional level, business and financial linkages, access to market information, improved capacity to comply with regionally and internationally accepted standards, regulations and practices, and policy and regulatory processes that lead to better integrated markets and expanded grain trade in the region.

By focusing on regional grain trade, the EAGC aims to improve market access for value chain actors, especially small holder farmers and small scale traders, and by so doing contribute to increased production, increased incomes, poverty reduction, and improved food security in Eastern Africa. The EAGC provides a regional institutional private sector framework to address issues affecting the grain industry in a holistic manner.

To achieve the above objectives, the EAGC has developed and implemented four key approaches which include:

1) an electronic regional grain trading platform, the Electronic Grain Trade Africa (EGTAfrica), under which the EAGC is developing and promoting the Structure Trading System;

2) provision of market information through the Regional Agricultural Trade Intelligence Network (RATIN); 3) training and capacity building of stakeholders through the Eastern Africa Grain Institute (EAGI); and 4) policy advocacy and dialogue to create an enabling policy environment through the Agricultural Trade Policy
Advisory Forum for Eastern and Southern Africa (ATPAF-ESA).

This paper discusses the provision of the market information system by the EAGC's RATIN. A description of RATIN is provided with a discussion of structure, conduct, and performance, as well as an examination of how RATIN has contributed to increased regional trade in grains in the Eastern Africa region, with a discussion of the challenges, lessons learned, and some conclusions.

\section{EAGC RATIN market information system}

\section{RATIN structure, conduct, and performance}

The EAGC RATIN market information system was initially developed by the USAID RATES program and later taken over by the EAGC when the EAGC was formed in 2006. It was recently redesigned, upgraded, and re-launched in 2012 in response to recommendations and user needs. The upgrade also took advantage of, and benefited from, recent developments in technology, including mobile applications, among others.

The upgrade process started with a detailed user survey conducted on behalf of the EAGC by Ipso Synovate, a leading market and opinion research agency in East Africa. The survey, which was commissioned in December 2011 and reported in February 2012, rated the level of RATIN usage and satisfaction by stakeholders. The survey which sampled 89 individuals, 60 of whom were EAGC members, revealed that there was a high awareness of RATIN across Kenya, Uganda, and Tanzania; the three countries targeted for the study. The awareness levels were highest in Uganda at 97\%, followed by Kenya at 83\%, and Tanzania at $62 \%$. With regards to satisfaction levels, 69\% reported that they were satisfied with delivery of MIS-related services (i.e. they rated quality of service as high).

In summary, the findings of the RATIN usage and satisfaction survey indicate high awareness and usage of RATIN products and services, including commodity prices, trade flow data, production data, and the food balance sheet data. Figure 1 summarizes the findings of the study in terms of awareness and usage of RATIN products.

A project team comprising of officers from the EAGC Secretariat, EAGC members, and the USAID COMPETE project held several planning and development sessions. A project initiation document (PID) was developed providing complete details of how the team envisioned the look, feel, and functions of the new RATIN system.

The aim of the survey was to determine the usability of RATIN among its main key audience. The survey targeted 40 stakeholders from each of the countries: Kenya, Uganda and Tanzania. The target included the private sector, some of whom were EAGC members and non-EAGC members. The respondents sampled also included policy makers, other MIS service providers, financial institutions, farmer groups, and apex farmer organisations.

The selection of the 40 respondents per country was guided by the master list developed by the EAGC through its country offices, on the main stakeholders in the region. The methodology was purposive sampling, since it targeted key stakeholders in the grain industry. The sampling was not based on those who had used RATIN before, but based on their participation in the grain sector.

From the findings, several respondents were aware of, and had used, RATIN, while a number were not aware of RATIN at all.

\section{RATIN System, infrastructure, and market data collection}

The structure of the RATIN system has several components. First, there is the system itself consisting of an internetbased database with data input, storage, processing, analysis, reporting, and interactivity functionalities (figures 2 and 3).

Second, is the field data collection which is undertaken by a network of border and market monitors who are provided with a smart mobile telephone, set up with a special application and GPS enabled. The first step of data collection and transmission is to log into the application. To log in, the telephone with the mobile application confirms the GPS coordinates that 
There is a strong correlation between awareness, usage and relevance of information services. Continuosly monitoring usage statistics of visitors to the RATIN site could be valuable stream of information to keep track of stakeholders' changing needs.

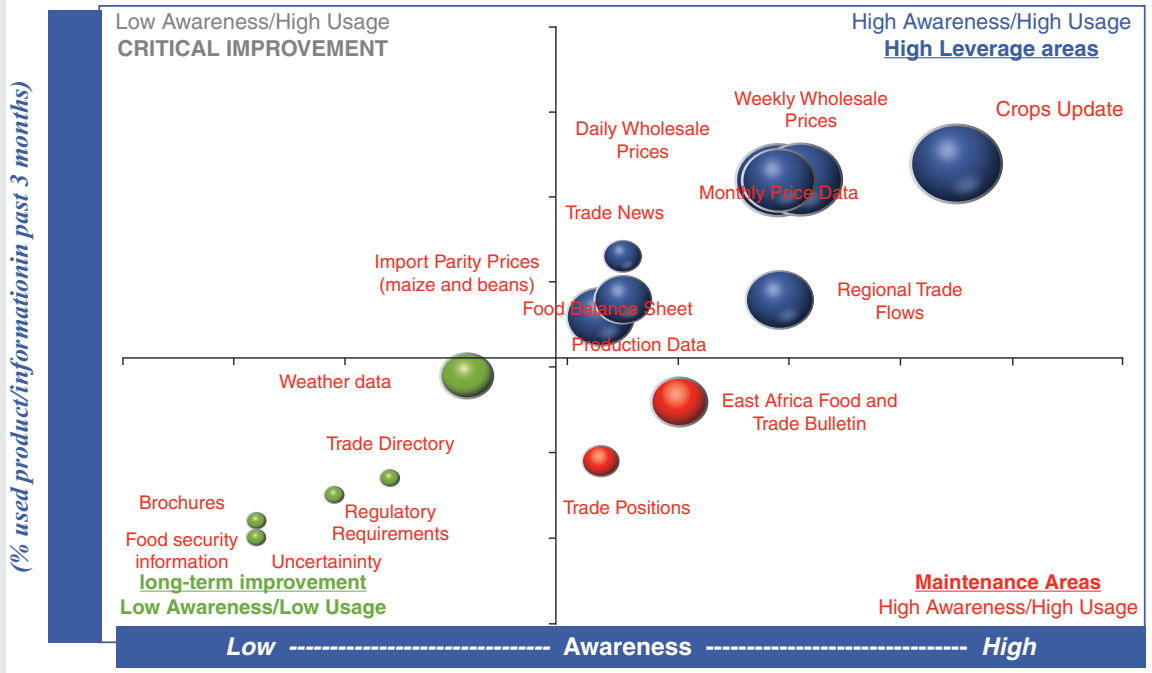

High Leverage areas

- Improvement increases usage

- Worsening reduces usage

Maintenance Areas

- Improvement does NOT

increases usage

- Worsening reduces usage

ong-term improvement

- Improvement does NOT

increases usage

- Worsening does NOT

reduces usage

(\% aware of product/information service currently offered on RATIN site.

Note: Bubble size represents \% mentioning product/ information service among 3 most relevant Ipsos Marketing

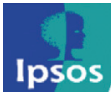

\section{Awareness and Usage frequency of RATIN}

Awareness of RATIN is the highest in Uganda at $97 \%$ and lowest in Tanzania however frequency of Usage amng those aware is highest in Tanzania where only $39 \%$ rarely or never use it compared to an average of over $45 \%$ in Kenya and Uganda.
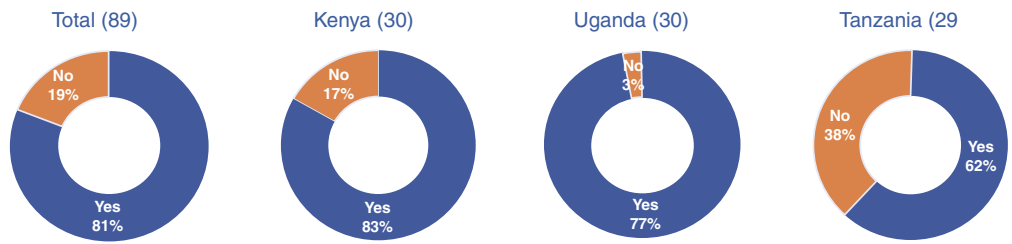

Usage frequency for those aware of RATIN

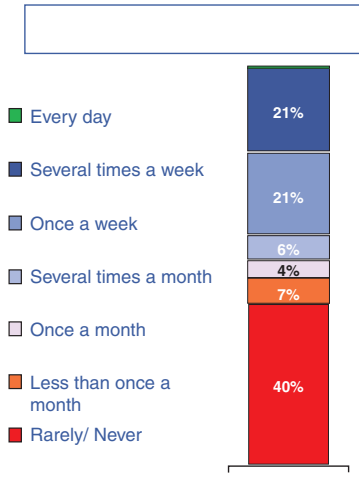

Total (72)

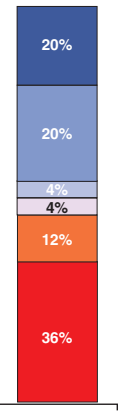

Kenya (25)

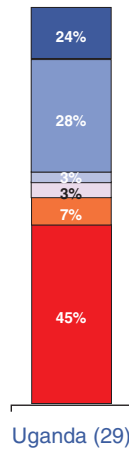

q3.1: Are you aware of EAGC's Regional Agricultural Trade Intelligence Network (RATIN) system? Q3.2: How frequently do you use RATIN?

Figure 1. Awareness vs usage of RATIN products/information services.

Figure 1. Sensibilisation des usagers et utilisation des produits de RATIN et des services d'information.

EAGC RATIN. Survey by Ipsos Synovate, 2012.

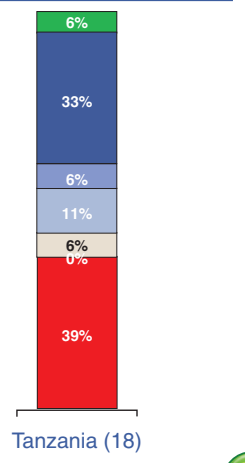

Ipsos Marketing 


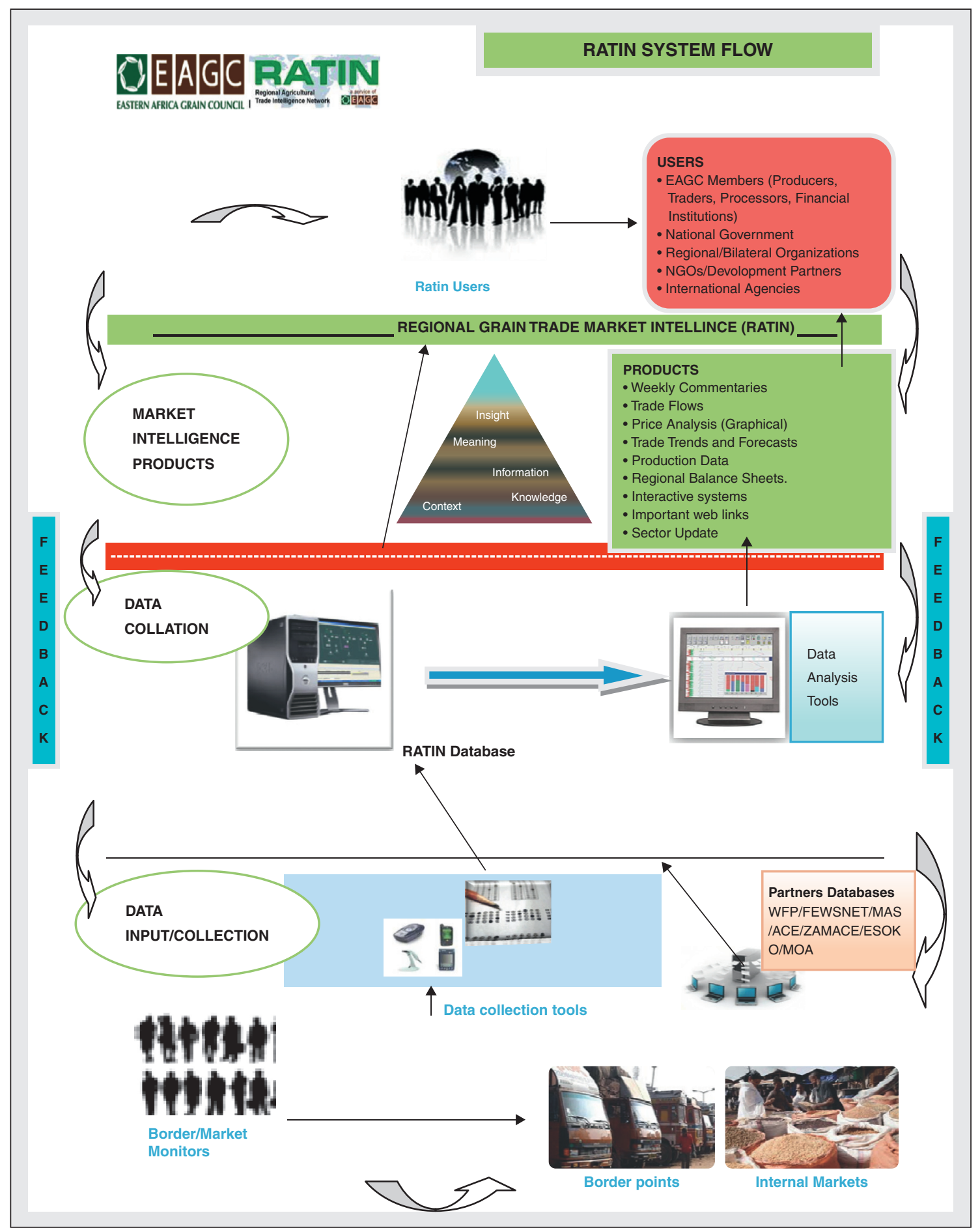

Figure 2. RATIN system flow chart.

Figure 2. Organigramme du système RATIN.

have been previously set to the specific location from where the monitor has been assigned to collect the data. The system confirms the location and then allows the monitor to $\log$ in and proceed to key in the observed market prices of the day for the listed commodities, and then submits the data directly to the system.

The EAGC RATIN enumerators are employed and compensated by the EAGC. They are also trained by the
EAGC using a very detailed training manual on standardized methodologies for data collection and entry that was developed with support of, and in partnership with, other international donor organizations. The manual has 


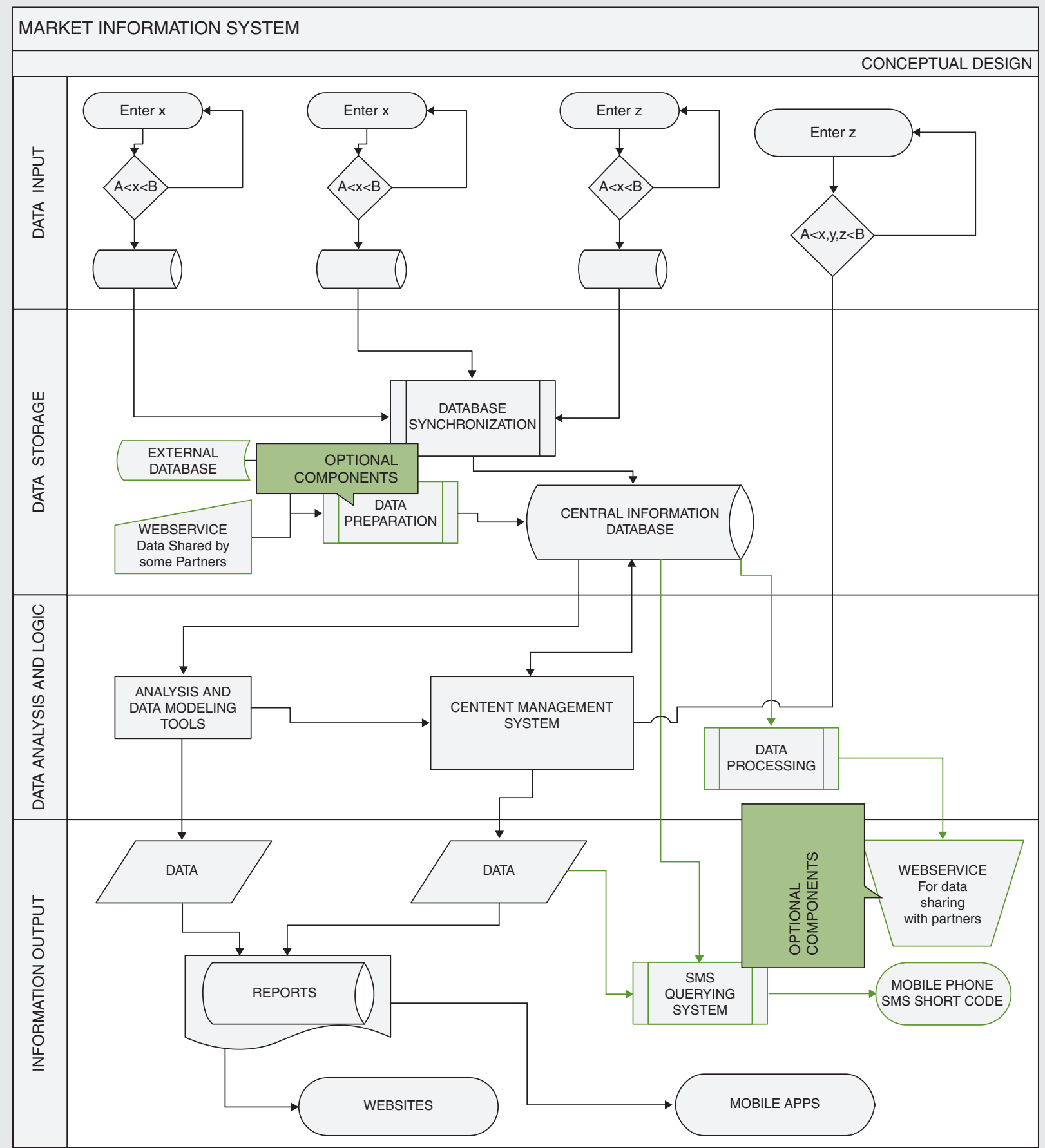

Figure 3. RATIN system conceptual process flow chart.

Figure 3. Organigramme du processus conceptuel du système RATIN.

EAGC, 2011.

been used to train monitors including those from partner organizations. This has tremendously improved quality and efficiency of data collection, as reflected in the findings of the end-term review.
The enumerators are male and female, most with college degrees. Prices are collected by enumerators speaking the local dialect and the price data disseminated in English, French,
Kinyarwanda, and Kiswahili. To ensure consistency, market prices are collected daily at between 06.00 and $09.00 \mathrm{a} . \mathrm{m}$. Border prices are collected continuously during the day. 


\section{RATIN products and service}

The data submitted from the markets and border points into the system server is further cross checked by the RATIN desk officer who checks for outliers, consistency, completeness, and accuracy of the data. Once satisfied, the data is then allowed into the main database from where it is available for users to view on the RATIN website on www.ratin.net or through the RATIN SMS Dissemination System by keying in the commodity and market, and sending the text to the RATIN SMS, e.g. maize, Kitale, and sent to +254705606666 for Kenya. Upon receipt of the SMS, the system responds with an SMS back to the sender, providing the data requested. On a weekly basis, the RATIN editorial team prepares a market analysis report and circulates it to the EAGC members and stakeholders in the mailing list.

RATIN has over 16 products which include daily market prices, daily crossborder trade flows, real-time warehouse stocks, regional food-balance sheets, parity prices, grain trade news updates, weekly market analysis reports, monthly cross-border reports, daily news updates, interactive maps and historical datasets, social media (Facebook and Twitter), Short Message Services (SMS), a telephone-based service, website display, and advertorial space (table 1).

The daily market price information for the selected commodities in selected key markets in the Eastern Africa region is usually available on the
RATIN website by 09.00, Monday to Friday. At the end of each week, the data is analysed for trends and comparisons and a report showing the market analysis is prepared by the editorial team and disseminated to members and stakeholders.

The Regional Food Balance Sheet (RFBS) is another product also hosted on the RATIN website. The RFBS is a joint partnership between the EAGC and several other partners, including: the EAC, the USAID, the Association for Strengthening Agricultural Research in Eastern and Central Africa (ASARECA), National Governments Ministries of Agriculture, and Strategic Grain Reserve Agencies, among others. The data in the RFBS is sourced from three key contributors; the private sector grain traders, warehouse operators, and grain millers/processors who provide their periodic closing and opening stocks and import/export projections, coordinated by the EAGC, the Ministries of Agriculture who provide data of production estimates, post-harvest losses, and stocks held in the National Strategic Grain Reserve Agencies, and finally the Relief Agencies. The RFBS provides data of food stock balances and estimations for imports, exports, consumption, and gives an indication as to whether the region faces a food deficit or surplus, and an appropriate policy response can be taken in good time to avert any food security crisis. The collection and compilation of production data in the region has been one of the challenges the EAGC has faced in developing the regional food balance sheet. The accuracy and reliability of the data was a challenge in the beginning. However, given the institutional framework on the regional food balance sheet, the quality assurance on the data provided is verified by the food balance sheet data national committees. This has minimised the margin of error which makes the RFBS very useful in the EAC region. Nonetheless, there is still room for improvement in the collection of production estimates data if appropriate systems can be put in place by the respective governments. The daily warehouse volume tracking is another service offered by the EAGC under RATIN. This is run through the system known as the "EAGC Real Time Volume Tracking" (RTVT) and is a mobile telephone-based application which is installed at the warehouses, registered under the EAGC. The warehouse operators feed in the data of stocks delivered, as well as stocks received in the warehouse, stocks by partners, and the sum of balance of stock that is available for sale.

The data is transmitted to RATIN and stakeholders have access; they can see where stocks are available for sale and can also contact a particular warehouse to initiate discussions on transactions.

\section{RATIN users}

The RATIN system is used by a crosssection of market actors, from

\section{Table 1. Summary of information offered by RATIN.}

Tableau 1. Résumé des informations offertes par RATIN.

\begin{tabular}{lll}
\hline Information & Data collection method & Dissemination method \\
\hline Daily market information & $\begin{array}{l}\text { Use of mobile phone - RATIN } \\
\text { Apps }\end{array}$ & $\begin{array}{l}\text { RATIN website, SMS, weekly market analysis report, } \\
\text { FAO Giews, FEWSNET, radio and newspapers }\end{array}$ \\
\hline Daily cross border trade flows & $\begin{array}{l}\text { Use of mobile phone - RATIN } \\
\text { Apps }\end{array}$ & $\begin{array}{l}\text { RATIN website, SMS, monthly cross border } \\
\text { analysis report, grain newsletters }\end{array}$ \\
\hline $\begin{array}{l}\text { Weekly market analysis report } \\
\text { Monthly regional food balance }\end{array}$ & Data analysis & $\begin{array}{l}\text { RATIN website, SMS, monthly cross border } \\
\text { analysis report }\end{array}$ \\
\hline sheet & National country contributors & $\begin{array}{l}\text { RATIN website, Policy briefs, newsletter, } \\
\text { regional newspapers }\end{array}$ \\
\hline $\begin{array}{l}\text { Daily warehouse volumes } \\
\text { Use of mobile phone - RATIN }\end{array}$ & $\begin{array}{l}\text { RATIN website, SMS } \\
\text { Apps }\end{array}$
\end{tabular}

Source : EAGC. 
producers to traders, processors, financial institutions/banks, researchers, and NGOs to national governments. RATIN is used by stakeholders for different uses.

Grain producers, traders, and processors/millers refer to RATIN in order to obtain the prevailing market prices and trends and locations with the highest and lowest prices, so as to make their buying or selling decisions. Researchers and policy analysts in the region use RATIN data for their research purposes including analysis, interpretation, and to obtain insights for study recommendations and policy briefs to various stakeholders. Policy makers use the historical price data collected in RATIN to analyse price trends and compute projections in order to make decisions of policy responses.

\section{RATIN and Warehouse Receipt Systems}

The Warehouse Receipt System (WRS) allows a grain producer or trader to deposit their grain produce in a certi- fied warehouse upon confirmation of the quality and quantity, and is issued with a warehouse receipt as proof of title of the warehoused commodity (figure 4). The depositor can then take the warehouse receipt to a bank or financial institution and can borrow up to $60 \%$ of the prevailing value of the warehoused commodity. While it may be possible for the holder of the receipt to sell the commodity forward and thereby "lock in" a price, the operation is normally of a speculative nature. The depositor waits and keeps monitoring market prices, and eventually decides to sell when the price meets his/her objective. On selling, the depositor transfers the warehouse receipt to the buyer and the money is paid through the bank that had advanced credit to the farmer. The bank deducts the principal loan and interest, the warehouse operator deducts the warehouse storage and grain handling charges, and the balance is paid out to the depositor (box 1).

RATIN has been the central point of reference to all WRS actors including the depositors (farmers or traders), buyers (traders or millers), and financial institutions who refer to the prevailing prices for the purposes of valuation of the stock to determine the amount of credit to advance to the borrower. The financial institutions also refer to RATIN to monitor the price trends and take action to avoid losses, e.g. calling for the sale of the produce, in the event that the produce price falls to a level that is near the price at which a loan was advanced, thus causing a risk to the recovery of the loan. This price level is called a "trigger price". Table 2 shows some warehouse volumes of various EAGC-certified warehouses in Kenya.

\section{RATIN and intra-EAC regional trade}

This section aims to provide evidence of the impact of RATIN on EAC regional trade.

As RATIN monitors the informal crossborder trade (ICBT) in grain in key selected borders in East Africa, it is

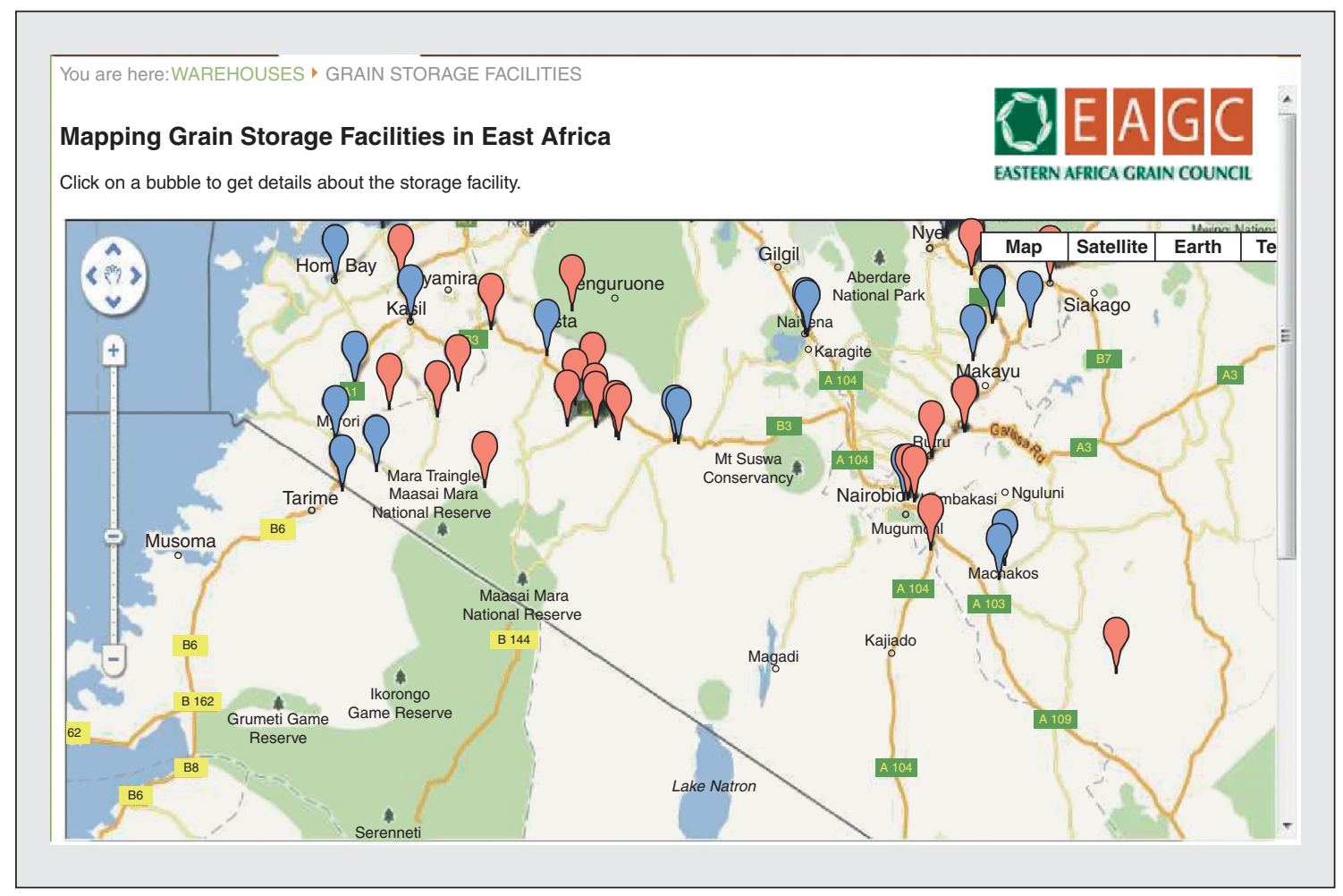

Figure 4. Mapping grain storage facilities in East Africa.

Figure 4. Cartographie des dispositifs de stockage de céréales en Afrique de I'Est. EAGC RATIN. 
Box 1

Testimony from a RATIN user

Ms. Maria Kioko is a member of Kasikeu Multipurpose Warehouse (located in Makueni Country, Kenya and supported by EAGC). Maria narrates: "Before WRS was introduced to us, we used to sell our produce to middlemen direct from the farm and never got any profit; we even ended up without food in our stores. However, after WRS was introduced, many of us decided to deposit our grains to wait for better prices. The price of grain has increased from Kes. 30, at harvest time to Kes. 72 by end of December, 2012. We are very excited about the stores and the fact that we can now borrow money easily. I harvested five bags of mbaazi (pigeon peas), three bags of cowpeas, and one bag of ndengu (green grams). With that safely stored in the warehouse and with the receipt I was given, I borrowed a loan from Kasikeu Financial Services Association (FSA), which I used to pay school fees and other necessities." Source: EAGC

possible to use RATIN data to see if this trade has increased over time. The evidence indicates that EAC intraregional trade in grains has been increasing over the years, although still at a low level (figures 5, 6, and 7). The regional grain trade flow indicates a continuous movement of grain across the borders, with Kenya being the main destination market serviced by Uganda and Tanzania, albeit through informal trade.

However, the quantities traded are highly unstable, suggesting that this trade mainly reflects the dynamics of production and consumption in the different countries (their trends and the instability of harvest levels in the different countries). Therefore, the growth of interregional trade recorded by RATIN monitors should be interpreted cautiously and does not provide any proof of RATIN's effect on regional trade.

The correct way to proceed is to consider the causality chains by which RATIN may have affected regional trade and to check if we can find evidence confirming that these causality chains have actually been activated.

Basically, RATIN can affect regional trade through two channels: i) advocacy leading to more stable and open regional trade policy regimes; and ii) better information of traders and other market players leading to more arbitrage and more trade across borders.

Regarding the first channel, government officials have reported making reference to RATIN while making policy decisions, such as import and export of grains. In the last two years, the region has enjoyed a continuous trade flow without import or export ban restrictions. RATIN and its services have been cited as one of the key reasons why there have been stable regional trade policy regimes. A temporary export ban placed by the Government of Tanzania in 2011 was later lifted following intense lobbying by stakeholders who made continuous reference to the EAGC RATIN information, thereby contributing to increased regional trade. In addition to data on prices and crossborder trade, the RFBS is likely to have played an important role in this area. Regarding the second channel, it should be emphasized that traders play a critical role in regional trade as they source produce by determining where supplies are in surplus areas and then moving them to the markets to meet demand in the deficit areas, thus providing a crucial link between farm producers and the market, millers/processors, and eventually to the consumers. However, the trade process of buying, transportation, drying, cleaning grading, packaging, and storage encapsulates the transaction costs which also include the resources spent to seek information on where to buy or sell a particular produce. Access to accurate, timely, and relevant market information is therefore a critical factor, the absence of which can hinder trade. However, stakeholders in agribusiness, farmers, traders, and millers have always cited the lack of market information, especially for agricultural produce, as one of the cardinal challenges they have to contend with, a factor that also increases their risk profile.

The EAGC RATIN provides different types of market information to support decision-making for trade purposes: daily market prices, price trends of various grains and cereals produced in the region, and cross-border trade volumes; imports, exports and warehouse volumes generated from the EAGC RATIN system, the information of which is available for reference by

\section{Table 2. Volumes of commodities deposited in various EAGC-certified warehouses in Kenya.}

Tableau 2. Volumes de produits de base déposés dans divers entrepôts certifiés d'EAGC au Kenya.

\begin{tabular}{llllllll}
\hline Commodity/seasons & 2008/09 & 2010/11 & 2011/12 & 2012/13 & $\begin{array}{l}\text { 2013/2014 } \\
\text { (deposits } \\
\text { ongoing) }\end{array}$ & $\begin{array}{l}\text { Cumulative } \\
\text { actual } \\
\text { (metric tons) }\end{array}$ & $\begin{array}{l}\text { Cumulative } \\
\text { actual } \\
\text { (90kg bags) }\end{array}$ \\
\hline Maize volumes (metric tons) & 921 & 527 & 850.82 & 1,812 & 4,049 & 8,159 & 89,754 \\
\hline Wheat volumes (metric tons) & 0 & 0 & 0 & 4,011 & 5,576 & 9,587 & 105,457 \\
\hline Pulses volumes (metric tons) & 0 & 0 & 0 & 138 & 0 & 138 & 1,518 \\
\hline & & TOTAL & & & 17,884 MT & 196,729 bags
\end{tabular}

Source : EAGC. 


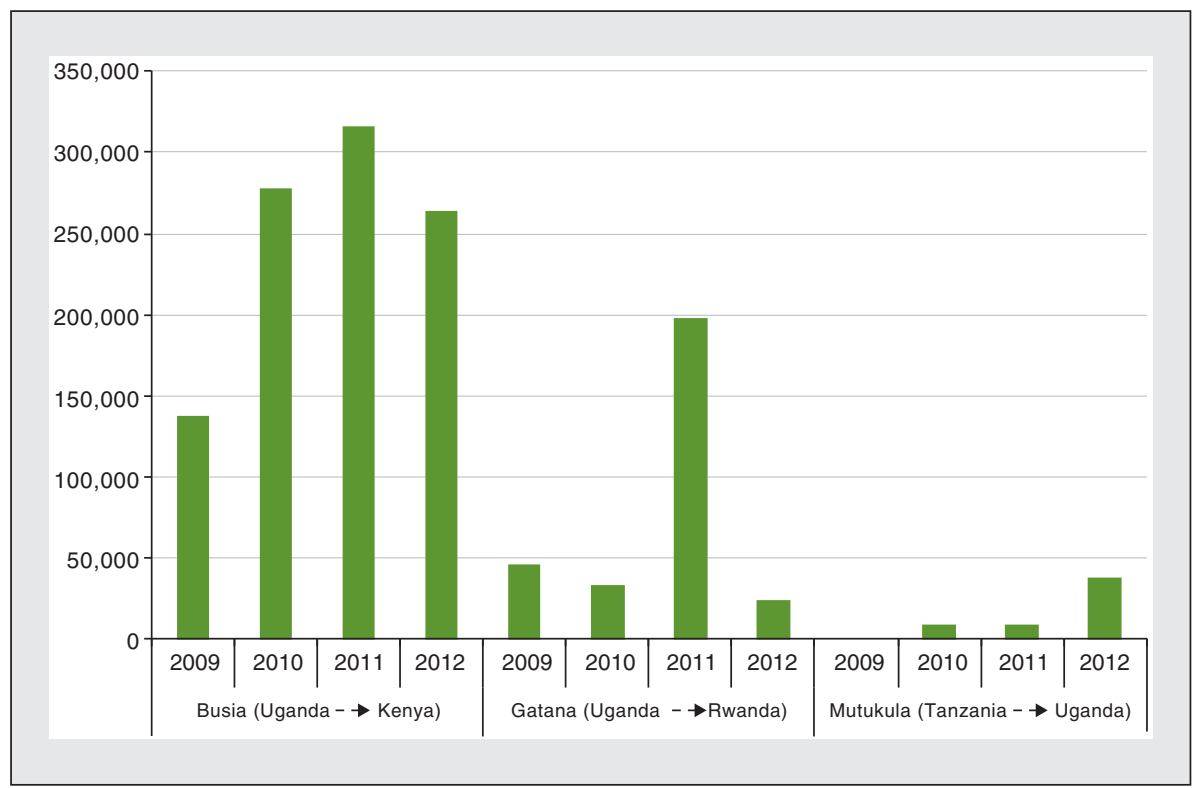

Figure 5. Maize trade flow at various border points (in metric tons).

Figure 5. Flux commerciaux de maïs à différents points de passage frontaliers (en tonnes). EAGC RATIN (www.ratin.net) stakeholders through the EAGC website and via mobile telephone SMS application. Through the EAGC RATIN, stakeholders in the region can obtain quick and real-time information about price trends and ware- house stock volumes in order to decide whether to buy, sell, or store. Since the establishment of the EAGC RATIN, and specifically the recent upgrade and re-launch, the market information system has increased a

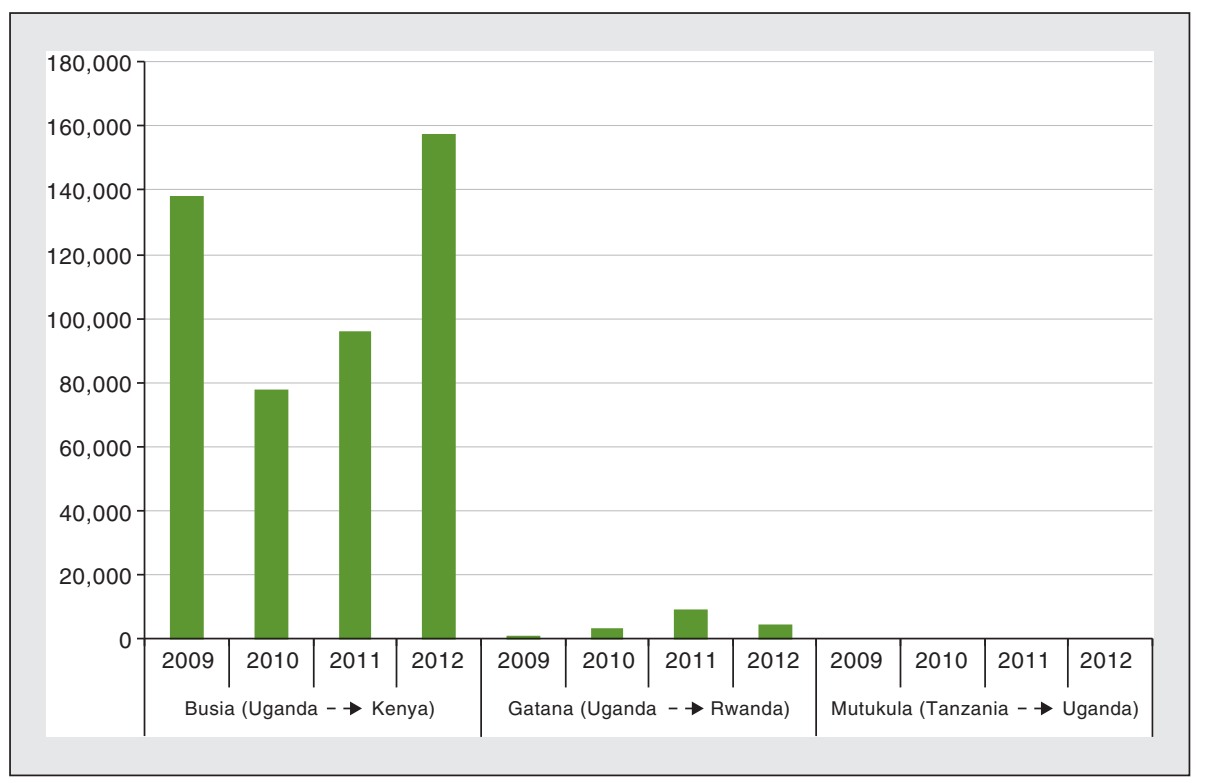

Figure 6. Bean trade flow at various border points (in metric tons).

Figure 6. Flux commerciaux de haricots à différents points de passage frontaliers (en tonnes). EAGC RATIN (www.ratin.net). notch with respect to provision and availability of information, and EAGC members have repeatedly reported that one of the major attractions to them signing up membership to the EAGC is the provision of market information.

Consequently, we can consider that the EAGC RATIN (which is now a respected credible and authoritative source of relevant, timely, and accurate market information) is likely to have contributed to regional trade facilitation by two channels: by strengthening advocacy in favour of more stable and open regional trade policy regimes, and by improving traders' information on the situation and dynamics of the regional grain market.

\section{RATIN business model and sustainability}

RATIN is owned by the EAGC and is primarily a service to EAGC members and other interested stakeholders. The basic information provided by RATIN, including price data, cross-border trade data, reports, and analysis, can generally be classified as a public good and is currently available to the public. The RATIN system upgrade and continued operations have been possible through financial support from development partners, including USAID and the Swedish International Development Agency (SIDA), ASARECA, and ICRISAT, among others. The donor support from the partners is used to pay the market monitors, system hosting, and staff and management of the System.

A business model for the sustainability of RATIN is under development. The sustainability drivers identified include various RATIN products and services that can be sold to members and other stakeholders, as well as some revenuegenerating services. These include data sales through subscription, data analysis and reporting, SMS data bundle sales, SMS info push services to registered users, and web advertising on the RATIN website. A detailed business plan with system marketing and publicity inputs, cost estimates, and projections of sales revenue is under preparation for review and implementation. 


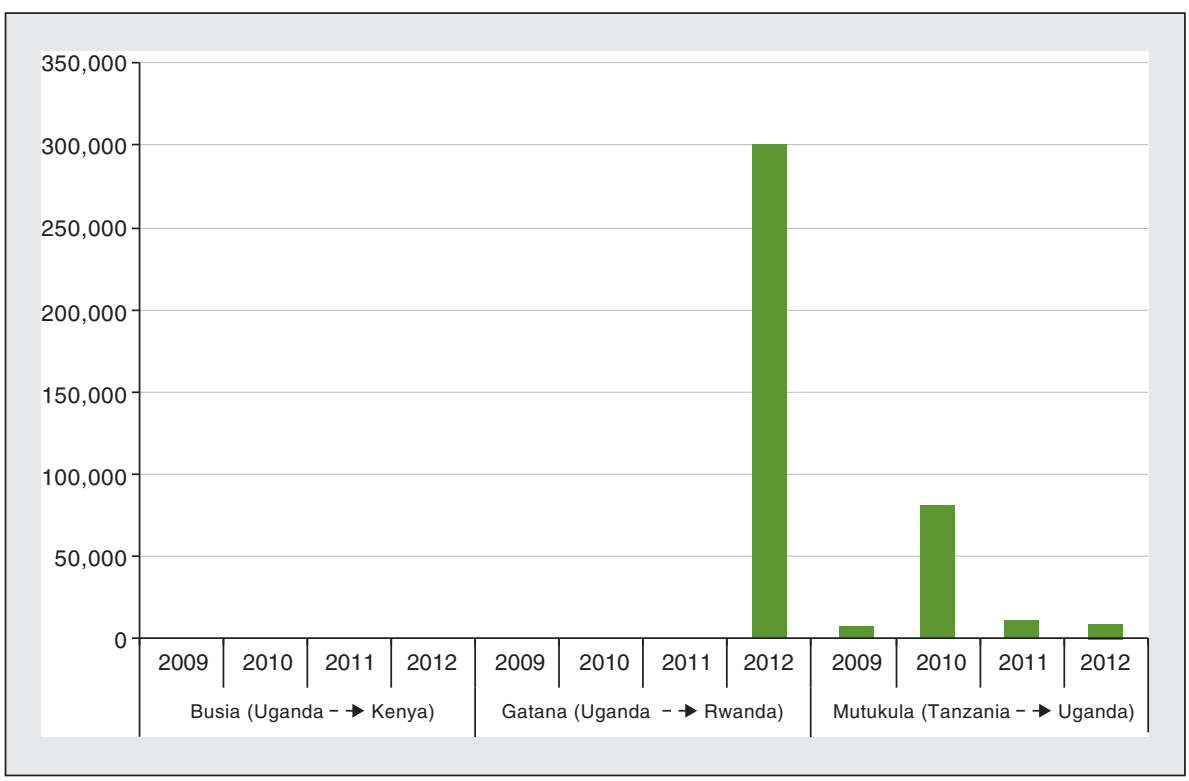

Figure 7. Rice trade flow at various border points (in metric tons).

Figure 7. Flux commerciaux de riz à différents points de passage frontaliers (en tonnes).

EAGC RATIN (www.ratin.net).

\section{RATIN achievements, challenges, lessons learnt, and}

\section{recommendations}

\section{RATIN achievements}

Since the EAGC completed the RATIN system upgrade and re launch in April 2012, the system has recorded several significant achievements. A number of lessons have been learnt through the process and these lessons continue to provide critical feedback for continued improvements of the Systems, products, services, and developing a sustainability strategy.

Some of the achievements of RATIN include: an increase in the number of commodities to 12 and markets monitored, improved efficiency, accuracy, and timeliness of the data submission through GPS-enabled smart telephones, improved data analysis and reporting, an increased userfriendly and interactive system where users query the data and perform same basic trending and statistical analysis online, and an efficient dissemination process through the new SMS system. RATIN has recorded an increased number of users since its re-launch facility cumulatively received 1,649 queries.

\section{RATIN challenges}

Designing, developing, and implementing a market information system that meets stakeholder needs is an onerous task. Firstly, establishing and balancing the needs among a diverse spectrum of users has been a challenge. Secondly, to attach a monetary value to a public good and find users who are willing to pay for the information is a challenge.

The costs of establishing and operating a market information system are substantial and so far have been financed by development partners who pick and choose specific elements and activities of the system that they find fashionable and interesting to fund. This has made it difficult for the EAGC to comprehensively address the sustainability process of the system and even invest in activities that contribute to the sustainability of the system, such as marketing and promoting the system to increase awareness and the user base for revenue generation.

\section{Lessons learnt and recommendations}

The best lesson learnt by the EAGC in this process is that it is indeed possible hits has increased since mid-2013, see figure 8). Meanwhile, the RATIN SMS

in April 2012. New users have also continued to log into the system. Between January 2013 and December 2013, the RATIN website received of 72,774 visits from 44,0 different visitors, generating a total of 8,001,083 hits on the different pages of the website (note this number of

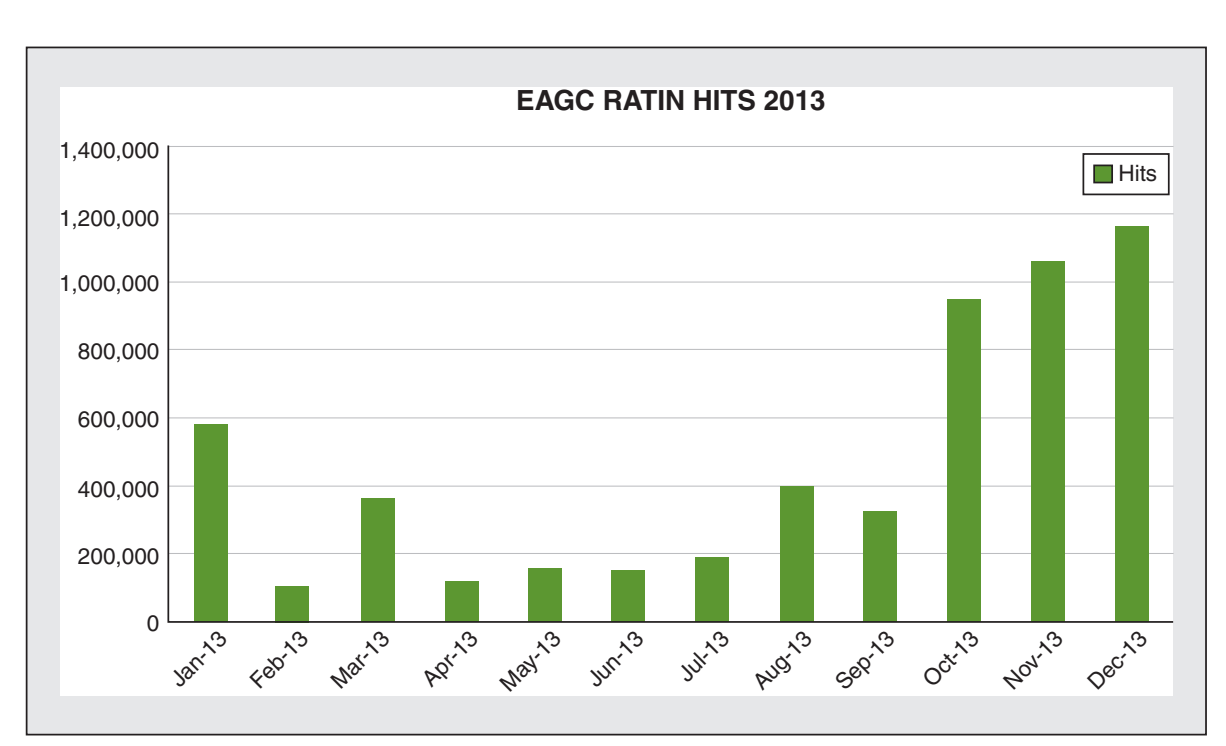

Figure 8. Number of hits on EAGC RATIN website from January to December 2013 (www.ratin.net).

Figure 8. Nombre de visites sur le site web EAGC RATIN de janvier à décembre 2013 (www.ratin.net). EAGC RATIN. 
to develop and implement a modern, user-friendly, reliable, accessible, and low-cost system that is appreciated and used by the stakeholders.

We have also learned that partnership and collaboration is paramount in making the process work. Critical to the success of the system have been stakeholder consultations to ascertain their needs for market information and designing a system that meets those needs.

A holistic approach and figuring out a sustainable business model for provision of market information is extremely important. A piecemeal approach and a pick-and-choose process in the funding of a market information system can be detrimental to the overall success and sustainability of the system.

Crowdsourcing, pooling of resources, partnerships and collaboration among organizations and institutions with an interest, and a mandate in market information is a potential strategy that can greatly boost the viability, success, and sustainability of a market information. It eliminates or reduces duplication, enables sharing of services, and avails more resources which are necessary for market information, both as a public good and a private good, contributing to enhancing regional trade, providing evidence for policy responses, and supporting business and policy decision-making.

\section{References}

AATF, 2004. A New Bridge to Sustainable Agricultural Development in Africa. Nairobi (Kenya): African Agricultural Technology Foundation. http:// aatf-africa.org/userfiles/AATF_Annual_Report.pdf

EAC, 2011. 4 ${ }^{\text {th }}$ EAC Development Strategy 2011/12-2015/16. Arusha (Tanzania): East Africa Community. http://www.eac.int/index. php? option $=$ com docman\&task = cat view\&gi$\mathrm{d}=155$ \& Itemid $=\overline{1} 63$ 